\title{
FEATURE Water rights and fights: Lao dams on the Mekong River
}

Kenneth R. Olson and Lois Wright Morton

$\mathrm{T}$ Mekong River is one of the world's most diverse and unique large rivers, and its flood pulse drives an extensive and productive ecological system (Campbell 2009). However, the capacity of the Mekong River basin to sustain fishery resources and upland and riverbank agriculture that provide food security and livelihoods for the people of Lao People's Democratic Republic (PDR) is strained by competing economic, ecological, and political interests. Development projects, such as dam construction on the Mekong River and tributaries to support a booming hydropower industry, are bringing great change to ecological, agricultural, and cultural systems in this region. The Laotian government has built many small "pocket" dams along tributaries (figure 1) and has proposed eight or more large dams on the Mekong main stem to meet energy needs for economic growth and to increase export revenues. Traditional fishing and agricultural systems are affected when dams submerge narrow floodplains and disrupt the timing and volume of river flows. As a result, dam building on the Mekong River main stem has become a source of uncertainty and unease in local river communities and has led to geographic and national unrest and conflicts (Campbell 2009; Nam Ou 2009).

This tropical, transboundary river is shared by six countries and over 60 million people, whose main protein source is fish. Originating in the mountains of Tibet and Yunnan Province, China, from an elevation of about 5,000 m (16,404 ft), it flows more than $4,350 \mathrm{~km}(2,700 \mathrm{mi})$ southward along Myanmar, Thailand, Laos, and Cambodia to the delta of Vietnam and into the South China Sea.The distinct characteristics of the

Kenneth R. Olson is professor emeritus of soil science in the Department of Natural Resources and Environmental Sciences, College of Agricultural, Consumer and Environmental Sciences, University of Illinois, Urbana, Illinois, and Lois Wright Morton is professor emeritus of sociology in the Department of Sociology, College of Agriculture and Life Sciences, lowa State University, Ames, lowa.

\section{Figure 1}

Hydroelectric power is produced from a small dam on a Mekong River tributary in the northern Lao People's Democratic Republic highlands. The reservoir behind the dams is used as a fishery and for irrigation.

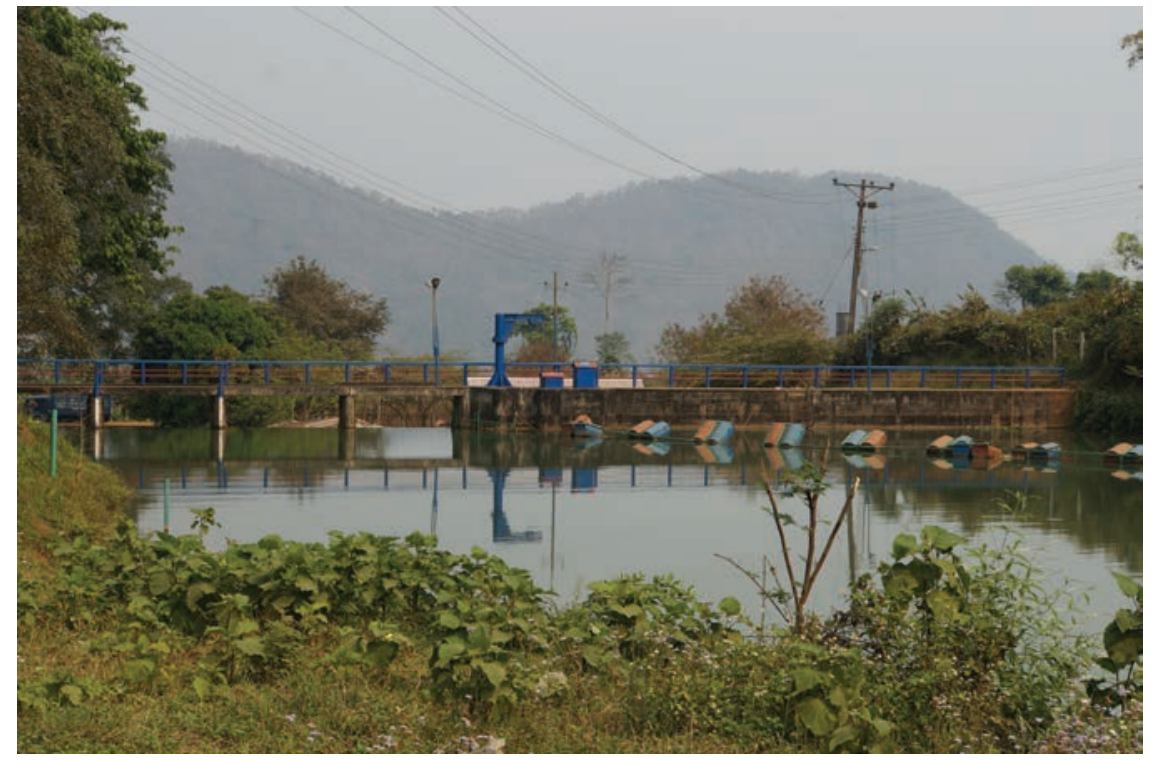

Mekong River basin reaches reflect historical tectonic events, climate, local variations in slope, soil profiles, erosion and sedimentation, and anthropogenic activities. The narrow gorges of the glaciated Himalaya Mountains confine the river, which widens slightly in northern Laos as the terrain alternates between mountain ridges and steep valleys with narrow floodplains. The river zigzags as it follows fault lines (figure 2) along bedrock walls. Plains are few and found primarily in the Mekong floodplain and along major tributaries where alluvial fans form at confluences with the main stem. Just north of the Lao capital ofVientiane, the Mekong flows through incised meanders that become short, straight reaches linked by sharp turns in the river. At Vientiane the Mekong lowlands begin, bounded on the west by the Korat Uplands (Thailand) and the north-south mountainous spine of the Annamite Range shared by Lao PDR and Vietnam (Gupta 2009).

Predictable seasonal flooding from the Southeast Asia monsoon and the local geology of the river influence the channel planform and sedimentation patterns that enable riverbank vegetables and rice (Oryza sativa L.) cultivation to follow receding wet season floodwaters (figure 3). Riverboats move farm products from field to home and markets, and tourists to scenic destinations until the dry season makes the river too shallow to travel. The Mekong River also provides habitat for a large variety of fish species, the rare Irrawaddy dolphin (Orcaella brevirostris), and a number of other endangered species. The challenge for the people of Laos and its government is to modernize their country, developing energy resources in ways that improve health and well-being and ensure livelihoods, while protecting abundant and diverse fish resources and ecologies of this large river system and the unique cultures it represents.

\section{GEOLOGY AND SOILS}

Early Quaternary and older alluvial deposits reveal the tectonic and sea-level adjustments, fold and fault lines, subsidence, and uplifts that characterize the evolving Mekong River (Carling 2009a). About 40 million years ago, its precur- 


\section{Figure 2}

The Mekong River originates in Tibet and the Chinese Himalayas and zigzags its way south through Lao People's Democratic Republic, Thailand, and Cambodia on its way to the South China Sea. Map by Mic Greenberg.

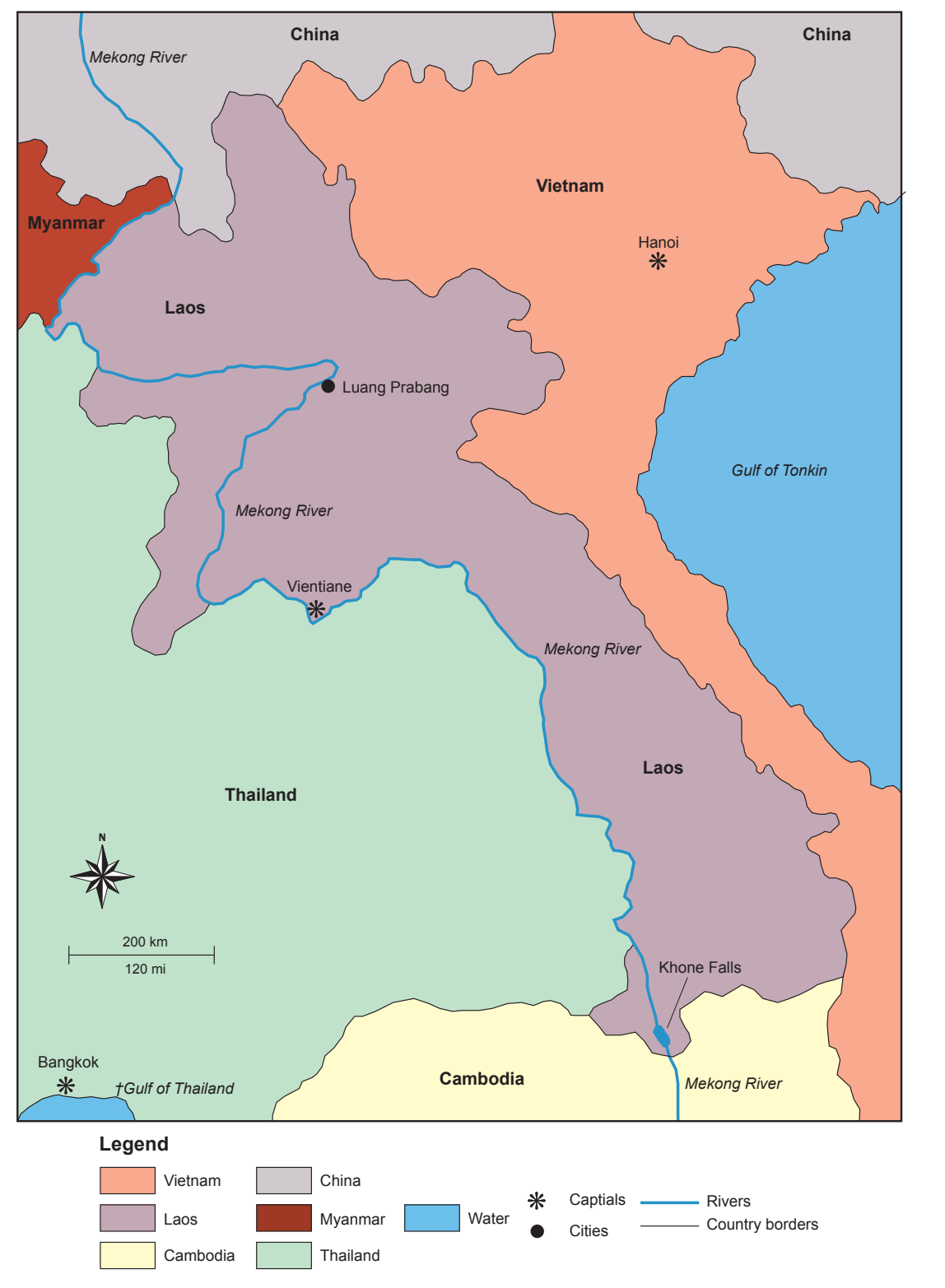

sor drained into the sea near where the Red River now flows just south of Hanoi, Vietnam. Over time, earthquakes and volcanic activity of the Himalayas altered the mountain drainage southward via steep gorges that appeared about 13 million years ago, and by 8 million years ago formed the present courses of three rivers: the Mekong, Yangtze, and Yellow rivers, which run in parallel sutures (Clift et al. 2006; Fenton et al. 2003).

Below this area was a wide inland sea during the Upper Mesozoic. It is likely mountainous region that have been mediated over time by glaciation, precipitation, and evapotranspiration (Carling 2009a).

The Mekong River channel has several distinct hydromorphological reaches as it flows south. In some places, the channel is fairly straight, but in other locations it becomes sinuous with high radius bends as it follows bedrock-carved (figure 4) fault lines and tectonic lineaments (Carling 2009a). As the bedrock-walled single channel flows into alluvial lowlands, the channel meanders with low radius bends. When the single alluvial channel at high flows takes a shortcut across the neck of a bend, the river becomes braided and divided, creating islands and multiple channels with water levels that vary with the season. FromVientiane to the Mun River confluence, natural levees composed of silt and clay about 8 to $10 \mathrm{~m}$ (26 to 33 $\mathrm{ft}$ ) high line both riverbanks, evidence of historical overtopping. However topping of these levees is not common today (Carling 2009b). Many wetlands beyond the levees are artificially drained for rice paddies, corn (Zea mays L.), vegetables, and other crops. Where the riverbanks are not steep, they are cultivated for flood recession agriculture, that is, planted according to the river level as it transitions from wet to dry season. The riverbed in this reach is fine sand with occasional outcrops of fluvial pebble beds with about 30 to $50 \mathrm{~cm}$ (1 to $1.5 \mathrm{ft}$ ) of organic rich or black inorganic silts (Carling 2009b).

Cretaceous volcanic activity occurred throughout southern Laos, and eruptions of basalts in the Miocene and Quaternary were widespread. The modern day Mekong River near the town of Muang Khong is locally controlled by basalt outcrops and fault patterns that give rise to the spectacular Siphandone (4,000 islands) and Khone Falls on the Lao-Cambodia border (Carling 2009a). The river in this reach has bedrock anastomosed channels overlain by alluvial deposits. This means that the river flows are separated by many large islands about 5 to $10 \mathrm{~m}$ (16 to 33 $\mathrm{ft}$ ) above the low water mark that sustain mature vegetation and are fairly stable or may migrate slowly from bank erosion.

\section{THE SOUTHEAST ASIAN MONSOON}

The Mekong River drains an area of $795,000 \mathrm{~km}^{2}\left(307,000 \mathrm{mi}^{2}\right)$ and discharges 
$457 \mathrm{~km}^{3}\left(110 \mathrm{mi}^{3}\right)$ of fresh water annually. Discharge volume and flood timing are highly predictable and concentrated in an extremely regular wet season peak (Adamson et al. 2009). The summer monsoon or wet season begins when warm moist winds from the ocean blow eastward over Thailand, Cambodia,Vietnam, and Laos and bring heavy rainfall. The onset of flood season occurs the end of June each year and lasts about 130 days. The start and end of the annual flood occurs within a period of two weeks with little variation. The dry season onset begins in late November.

The left-bank (eastern) tributaries of the Mekong receive high levels of rainfall from the monsoon as moisture-laden winds encounter the ridges and mountains of Laos. In northern Laos 14 tributaries drain into the Mekong River, including the $447 \mathrm{~km}$ (278 mi) long Nam Ou River, the longest Mekong tributary river in Laos. Runoff from Lao tributaries are the source of major wet season flooding and Mekong River discharge (Adamson et al. 2009). The largest single tributary of the Mekong is the Mun River of northern Thailand at $673 \mathrm{~km}$ (418 mi). However, despite its length, the Mun drains a dry, flat region and contributes a very small portion of the Mekong's discharge.

\section{FISHING, FORESTRY, AND AGRICULTURAL SYSTEMS OF LAOS}

The people of Laos derive their incomes from fishing, agriculture, and forestry. The longest river in Southeast Asia and the seventh longest in the world, the Mekong is considered by many to be the world's most productive inland fishery. Its wellknown giant fish include the Mekong catfish (Pangasianodon gigas), the giant barb (Catlocarpio siamensis), Julien's golden carp (Probarbus jullieni), and two probarbids (Probarbus labeamajor and Probarbus labeaminior) (Campbell 2009). Laotians and Cambodians catch more freshwater fish per capita than any other people worldwide (Ferguson et al. 2011). The more than 500 known species of Mekong River fish have sustained millions of people through droughts, deluges, and even the genocidal Cambodian regime of Pol Pot. Fish are grilled, fried, or boiled; wrapped in palm leaves; garnished with ant eggs; or simply

\section{Figure 3}

As the wet-season floodwaters recede, gardens and crops are planted on the riverbanks and benefit from the residual soil moisture during the dry season. This photo was taken in March of 2016 at the height of the dry season.

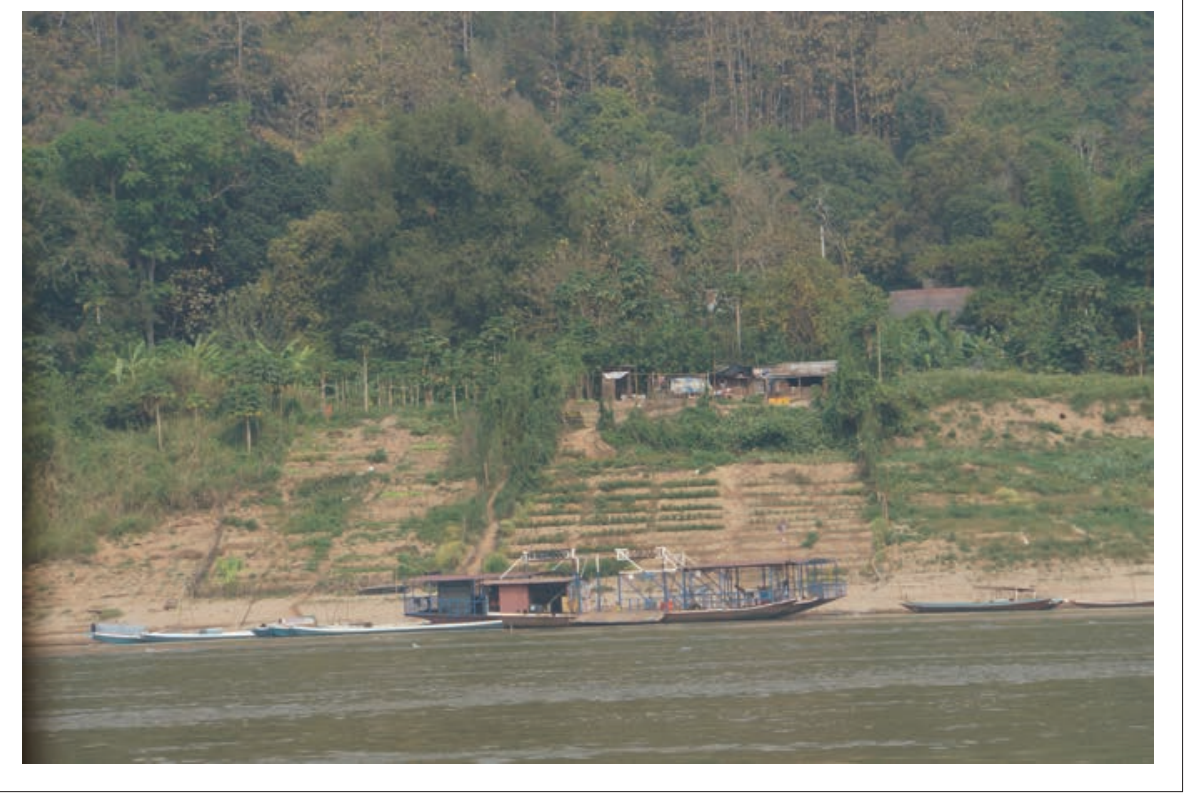

mixed into a wooden bowl with rice. In addition to being used fresh, fish are preserved by drying and pickling. The main fishing seasons are March through April and November through December, with women catching smaller fish and the men catching the giant fish. Fish production is a central part of river communities' social and economic activities ranging from managing fisheries to fish processing and marketing.

Many kinds of crops are grown on the banks of the Mekong River and its tributaries and within narrow floodplains. Flood recession agriculture is practiced extensively to cope with annual wet season flooding and dry season conditions. This type of farming uses the residual soil moisture stored in the soil profile after the rainy season flooding. Sedimentation of fine-grained materials under a seasonal flooding environment develop clayey soils (e.g., vertisols, fluvisols, gleysols, and camisols) with high water retention (Kyuma and Kawaguchi 1966; Olson and Morton 2017), which allows cropping during the dry season as river water levels drop.

Laotian farmers plant vegetables, melons, rice, corn, peanuts (Arachis hypogaea), and other crops on sloping riverbanks (figure 3) for family use and local markets. The predictability of the wet season flooding and onset of the dry season reduces risks of crop loss and enables farmers to match specific crops and flood-tolerant varieties to the river stage and bank location as the flooding recedes. Flood recession farming has been practiced for generations along the Mekong River, and the local knowledge on which crops and varieties perform best under specific practices is specific to each village and its location within the reach.

Vegetable plots are also found in the valleys of tributaries near small mountain villages and cities, such as Luang Prabang, Laos. These plots must be irrigated daily during the dry season to ensure productivity and are watered manually. A number of tributaries have small pocket dams that are used for irrigation, fisheries, and hydroelectricity (figure 1).

Laotian farmers and fishers supplement their food and incomes by raising cows, pigs, buffalo, and small animals such as ducks, geese, and chickens. Wild mushrooms, bamboo, and herbs are also gathered by women and children for family use and village markets. The Mekong River valley in China is famous for rubber tree (Hevea brasiliensis) plantations, and the plantations have spread into Laos, Myanmar, and Vietnam. The mountain slopes and valleys 
are often cleared and farmed.The northern Lao highlands, with 30\% to $60 \%$ slopes, are planted to pineapples (Ananas comosus) and other tree crops including teak (Tectona grandis) and rubber trees (figure 5).

Lao PDR has over 150 ethnic groups including the Khmer, Hmong, Mien, Tai, and Rau. The Tai and Hmong peoples came to the Lao and Vietnam highlands from China during the 1860s as refugees from Qing armies (Goscha 2016). One Hmong mountain village about $20 \mathrm{~km}$ (12 mi) south of Luang Prabang is adjacent to a rubber tree plantation (figure 5) and offers a glimpse of life in Lao rural highlands. The village is home to about 50 families living mostly in thatch huts with a United Nations Educational, Scientific, and Cultural Organization (UNESCO) water supply source and electricity. While most of the village homes have packed dirt floors, new construction underway involves cement floors and support beams. A communication reception dish is visible outside one of the village buildings, and cell phones are used by a number of young people.

\section{NAVIGATION ON THE MEKONG RIVER}

The Mekong River is a major trade route between western China and Southeast Asia notwithstanding the extreme seasonal variations in flow and the presence of rapids and waterfalls. Volumes of goods shipped decrease by more than 50\% during the June to January dry season (Mekong River Commission 2010). Despite dangerous rock outcrops in the river, trade volumes are expected to increase $8 \%$ to $11 \%$ annually. New facilities are planned for Chiang Saen Port, Thailand, where over 300 vessels fly Chinese flags (Mekong River Commission 2009).

The Mekong River is used to ship goods and produce between Thailand and Vientiane. In Laos, 50 to 100 vessels are operated for regional trade. The main cargo include timber, construction materials, and agricultural products. There is a large tourist trade in the region, and long boats (figure 4) take tourists on river cruises to view limestone caves in the cliffs with stops at villages that weave silk and cotton fabrics and rugs. The Golden Triangle, where Lao PDR, Myanmar, and Thailand meet, is northwest of Luang Prabang on

\section{Figure 4}

Limestone caves and cliffs tower over the Mekong River. The flood of 2008 reached the top of the stairs to a cave that tourists frequently visit and covered more than three-quarters of the cave opening.

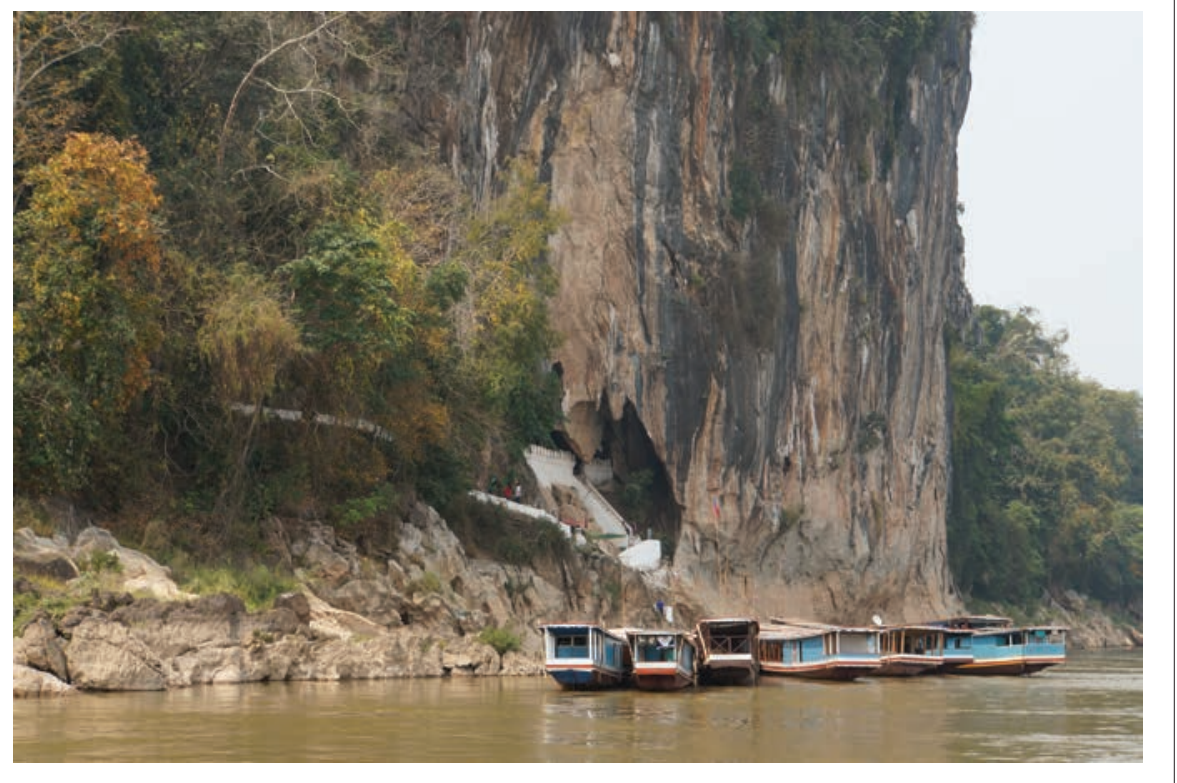

the Mekong River. It is infamously known for river drug traffic that local and national governments of all three countries continually attempt to police.

\section{DAMS AND HYDROELECTRIC POWER}

Today Southeast Asia is relatively peaceful, and economies are strengthening. However, only one-third of Cambodians and just over two-thirds of Laotians had electricity in 2016. The Mekong basin is home to some of the world's poorest people, and power is extremely expensive. An increasing population and economic growth are projected to further strain electricity supplies. A 2013 analysis by the International Energy Agency predicts the region's demand for power will exceed the supply without the construction of dams and reservoirs (IEA 2013). Demand is expected to increase by $80 \%$ before 2020. The region needs more energy, and the hydropower potential of the Mekong River is huge. Further, in an era of climate change and the need to reduce carbon (C) emissions, hydropower produces energy with very small $\mathrm{C}$ footprint (Greater Mekong Subregion Atlas of the Environment 2012). Currently, there are about 60 small pocket dams on Mekong tributaries that are used for electricity and irrigation, but they do not appreciably alter the consistent flow of the Mekong River (Adamson et al. 2009) or provide sufficient energy to meet Lao domestic and export demands.

The Mekong River has long tempted dam builders to tame the river for navigation, irrigation, and electricity. In the 1960s, the United States advocated the construction of a series of hydropower dams on the lower Mekong River. The goal was to develop the region's economy and head off the rise of communism in Vietnam. The plans languished, the region descended into war, and in the 1990s China - not Southeast Asia-built the first dam on the main stem of the Mekong River (Greater Mekong Subregion Atlas of the Environment 2012).

Eight or more dams are proposed by Lao PDR on the Mekong main stem, almost all designed for hydropower generation rather than water extraction for irrigation (Adamson et al. 2009) or to improve navigation since they will not have mechanisms for boats to lock through. Xayaburi Dam and the Don Sahong Dam are the first two under construction. These dams will increase dry season water availability (via the reservoirs behind the dams) and potentially reduce wet season flows. 


\section{Figure 5}

Rubber trees grow in a plantation near a Hmong village south of Luang Prabang, Lao People's Democratic Republic.

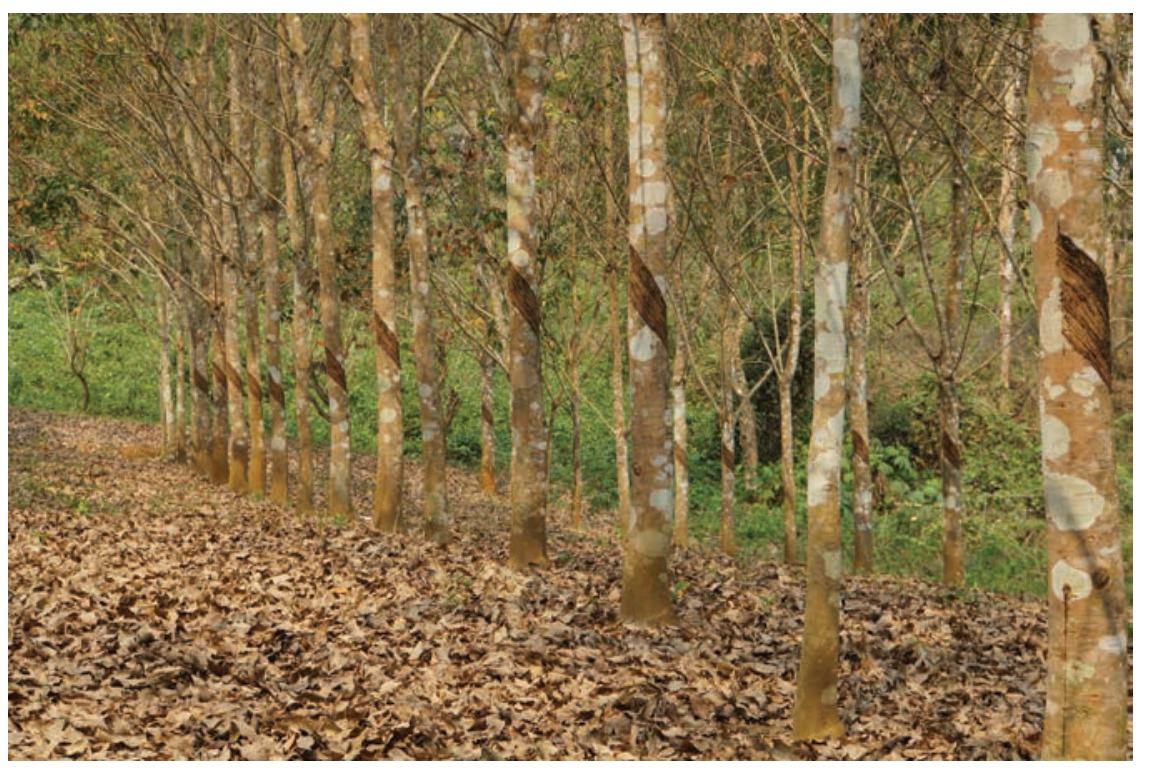

The implications for people who derive their livelihoods from fishing and riverbank agriculture as well as resettlement of villages flooded from the dam reservoirs are great concerns to local communities. Many claim they have not had access to accurate information during the dam planning and construction stages and lack knowledge about dam impacts on their fishing grounds and farmlands. Further, few local people have been asked to share their knowledge, perspectives, or recommendations in resettlement, training needs, and dam impacts to their community. Many are fearful about reduced fish catches, loss of farmland, reduced family income, patterns of river travel, compensation for loss of land and homes, and loss of their traditional ways of life (Vaddhanaphuti and Gyorvary 2015).

The 1995 establishment of the Mekong River Commission (MRC) was intended to implement a four-country agreement (Lao PDR, Thailand, Cambodia, and Vietnam) of cooperation to achieve sustainable development and conserve water and related resources of the Mekong River basin. It is no small task for the MRC to provide governance and negotiate ecological, social, economic, and political balance across countries when it has no legally binding authority (Campbell 2009). In 2010, an environmental assessment sponsored by MRC called for a 10-year moratorium on construction of main stem dams, citing the devastating effects on regional food supplies and the likelihood of irreversible environmental damage. The 10 to 11 main stem dams proposed by Laos and Cambodia have undercut the power of the MRC.

\section{RIVER CONFLICTS}

For hundreds of years the Mekong River basin has been the center of many human conflicts. After World War II, the region was torn by wars of independence as colonial powers attempted to reestablish themselves, and national people resisted (Goscha 2016). Intercountry conflicts and small-scale border skirmishes have retarded regional development and left Mekong countries with residual suspicion of each other that makes cooperation and joint river management difficult. In mountainous Laos, the Mekong River is the lifeblood of the country, but has resulted in many of years of armed conflict over the control and use of the river and adjacent floodplain soils. Lao dam building plans and management decisions have intensified the human conflicts.

Laos is now courting foreign investment with the goal to become the "battery" of Southeast Asia by selling hydroelectricity to Thailand and other nearby countries including Myanmar,
China, Cambodia, and Vietnam (figure 2). Neither Vietnam, a traditional ally, nor the MRC has been able to stop Laos from building the Xayaburi Dam about $145 \mathrm{~km}$ (90 mi) south of Luang Prabang. It will be the first dam south of the China border constructed across the main stem of the Mekong River in Lao. There is worldwide concern that the Xayaburi Dam could open the door for more dams across the Mekong River (figure 6).

The Lao PDR government finally admitted in 2012 that construction of the Thai-financed Xayaburi Dam was underway. The dam will be approximately 30 $\mathrm{m}(100 \mathrm{ft})$ high and more than $1 \mathrm{~km}(0.6$ mi) wide and scheduled for completion in 2018. However, protests and conflicts have delayed completion. Foreigners are no longer allowed to visit the construction site. One of the last foreigners known to have visited the site in 2013 observed the upstream river banks were being used as sand and gravel pits for extraction of material for both dam and road construction (Nijhuis and Guttenfelder 2015). Cranes hung over the Mekong River, and workers were using explosives to cut terraces in the steep river sideslopes in preparation for filling with cement.

Many are concerned that the Xayaburi Hydropower Dam could cause irreversible and long-term ecological damage to a river that feeds millions of people, force the resettlement of 2,100 , directly affect 202,000 people who use the Mekong bottomlands to produce food, and may push endangered fish, such as Mekong giant catfish, to extinction. A village next to the dam site will be covered by reservoir water. It is being moved out of the valley upstream where new housing is being built. Downriver another village must also be moved out of the river canyon.Villagers have been promised new homes built of cinder blocks and wood in the new location. The villagers are poor and live off the fish and rice that they grow in the Mekong bottomlands. Their main traditional crop, rice, is not suited to upland soils where the village is being relocated. Traditional fishing areas upstream will be covered by the reservoir water, and villagers must learn new ways of fishing. The potential impacts of the reservoir and dam on downstream 


\section{Figure 6}

Existing and proposed dams on the Mekong River main stem by China, Lao People's Democratic Republic, and Cambodia. Map by Mic Greenberg.

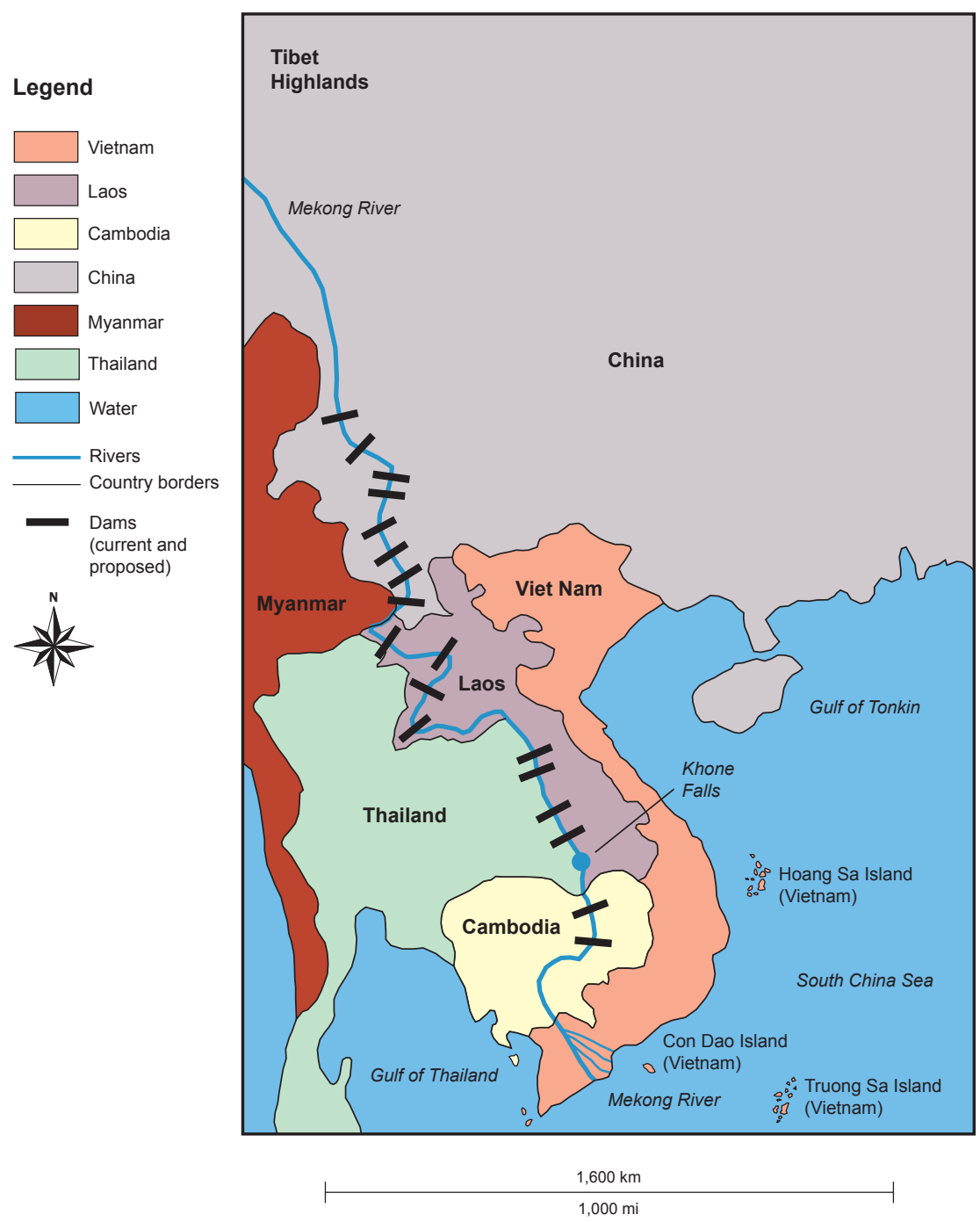

Mekong River fish populations are not well understood.

\section{INTERNATIONAL AND LOCAL PROTESTS AND KILLINGS OVER XAYABURI DAM}

Attempts by the Lao government to build the Xayaburi Dam have been challenged by adjacent countries, the international community and environmentalists, and China. In January of 2013, a group of Thai activists gathered near the Mekong River in Ban Huay Luek, northern Thailand, after a 123 $\mathrm{km}$ (77 mi) walk along the river (Nijhuis and Guttenfelder 2015). Led by Buddhist monks and joined by farmers, politicians, and foreign backpackers, many had spent two weeks on the road, camping in the courtoutcome has not been changed. reaches from bank to bank. More recently, dam construction has resulted in two bomb incidents, one resulting in injuries to workers. Timber clearing workers from China have also been shot. The site of the reservoir is now off limits to anyone not associated with the construction work; this is enforced by a Lao military checkpoint on the road leading to the reservoir.

Armed conflict has expanded to six incidents of sniper shootings along the 200 km (150 mi) long Route $13 \mathrm{~N}$ between Vientiane and Luang Prabang, the two largest cities in Laos. Between November of 2015 and March of 2016, 28 civilians were wounded and 6 others killed. The US State Department issued a warning on March 6, 2016, to citizens to avoid traveling on Route $13 \mathrm{~N}$ between the two cities. Later in March of 2016, a bus from Kunming, China, was driving along Route $13 \mathrm{~N}$ between Luang Prabang and Vientiane, and 11 protesters shot and killed a pickup truck driver in front of the bus and then opened fire on the bus (Boliek 2016). Eleven passengers, mostly Chinese workers or tourists, were wounded. It appears this was a protest against building the Xayaburi Dam and an attempt to discourage foreign tourists. The Lao government seems to have discouraged reporting of the armed conflict; stories were only covered by Southeast Asian newspapers and on local radio. The Lao PDR Army is attempting to stop the shootings, but the mountainous terrain contributes to difficulty tracking the protesters. As of April of 2016, there had been no public release of evidence or indication of the responsible party. to draw public attention to the proposed dams. Despite a letter writing campaign to Lao PDR and Thailand governments and protests, the Xayaburi Dam construction

Many years earlier, when the Chinese government attempted to clear a section of the Mekong for boat traffic in the dry season by dynamiting river rapids and falls, northern Thailand protesters successfully kept them from finishing the job. Many of these veteran protesters have joined the dam construction protests. In 2014, a national Thai court agreed to hear the Xayaburi case, but it is likely too late to block the construction since it already

\section{CONCLUSIONS}

The defining characteristics of the Mekong River today are "its single, smooth, and regular flood peak and the consistent size and regularity of that peak" (Adamson et al. 2009). The people of this region and the ecology of the river are highly tuned to this regularity. The loss of this predictability with the construction of dams on the main steam is the single greatest concern of those who earn their living from the river and those who value its unique ecology. How will dam management of floodwaters and release of water during the dry 
season affect the river hydrology, habitats, and species that live there? Will the water releases be consistent and predictable so fishers and farmers can effectively adapt? If water is held in pools behind the dams, will there be sufficient water for downstream users? There are many unknowns about the resilience of the Mekong River if one dam, two dams, or many dams are built across the main stem.

The loss of riverbank and floodplain farmland will be substantial for both relocated villages and villages along the new reservoir that must learn new skills in upland regions that have very little topsoil and are not suited to cultivated cropping systems. The new dam-reservoir ecological system may change fish species and abundance, fishing techniques, and uses of river resources (panning for gold, harvesting riverweed, and big shrimp) (Nam Ou 2015). The greatest impacts of Mekong main stem dam building to-date is on fishers and farmers and the psychological fear that comes from lack of information that limits capacities to adapt. Villagers are not fully involved in the dam planning or construction stages, are not informed or invited to be part of the process, and as a result are very frightened and afraid (Vaddhanaphuti and Gyorvary 2015). They do not trust developers and are worried about where they will live and how they will provide for their families. Without accurate details on the dam planning and building process and its potential impacts on the river, it is difficult for them to learn new ways, adapt, and prepare for a changed situation.

Sustainable development of the Mekong River will need an integrated approach of technologies and active engagement of farmers and fishers in information exchanges and decisions to ensure the transition is beneficial to people and the river basin. There is little doubt that hydroelectricity is a key resource in providing needed energy, modernization, and economic vitality to Southeast Asia. The question is, how can the Mekong River resources be well utilized to realize the goals of many without compromising the river's capacity to continue to meet the needs of the region into the future? Dams are only one of many threats to the sustainability and resilience of the river. A changing climate, deforestation of uplands, and irrigation needs of a growing population are other difficult issues the governments and peoples of the region must address.

As a transboundary river, management decisions by one country inevitably reverberate throughout Southeast Asia. The MRC is a critical institution that all Southeast Asia countries must respect and reempower to negotiate and balance the many competing interests. One of the MRC's major tasks will be to mitigate the negative impacts of dam building while realizing the benefits.

\section{ACKNOWLEDGEMENTS}

Published with funding support from the Director of the Illinois Office of Research, College of Agricultural, Consumer, and Environmental Science, University of Illinois, Urbana, Illinois, and the Iowa Agriculture and Home Economics Experiment Station, College of Agriculture and Life Sciences at Iowa State University, Ames, Iowa.

\section{REFERENCES}

Adamson, P.T., I.D. Rutherfurd, M.C. Pell, and I.A. Conlan. 2009. Hydrology of the Mekong River. In The Mekong Biophysical Environment of an International River Basin, ed. I.C. Campbell, 53-76. New York: Elsevier.

Boliek, B. 2016. Chinese man killed and others injured in Laos shootings. Radio Free Asia. Reported by RFA's Lao Service. March 3, 2016. https://www.rfa.org/english/news/laos/ chinese-man-killed-others-injured-in-laosshootings-03032016154247.html.

Campbell. I.C. 2009. The Mekong Biophysical Environment of an International River Basin. New York: Elsevier.

Carling, P.A. 2009a. Geology of the Lower Mekong River. In The Mekong Biophysical Environment of an International River Basin, ed. I.C. Campbell, 13-28. New York: Elsevier.

Carling, P.A. 2009b. Geomorphology and sedimentology of the lower Mekong River. In The Mekong Biophysical Environment of an International River Basin, ed. I.C. Campbell, 77-111. New York: Elsevier.

Clift, P.D., A. Carter, I.H. Campbell, M. Pringle, V. Nguyen, C. Allen, C.M Allen, K.V. Hodges, and T.T. Mai. 2006. Thermochronology of mineral grains in the Red and Mekong Rivers, Vietnam: Provenance and exhumation implications for Southeast Asia. Geophysics, Geosystem 7(10):1-28.
Fenton, C.H., P. Charusiri, and S.H. Wood. 2003. Recent paleoseismic investigations in northern and western Thailand. Annals of Geophysics 46(5):957-981.

Ferguson, J.W., M. Healy, P. Dugan, and C. Barlow. 2011. Potential effects of dams on migratory fish in Mekong River: Lessons from the Frazer and Columbia rivers. Environmental Management 47(1):141-159.

Greater Mekong Subregion Atlas of the Environment. 2012. Manila, Philippines: Asian Development Bank.

Goscha, C. 2016. Vietnam. A New History. New York: Basic Books.

Gupta, A. 2009. Geology and Landforms of the Mekong Basin. In The Mekong Biophysical Environment of an International River Basin, ed. I.C. Campbell, 29-51. New York: Elsevier.

IEA (International Energy Agency). 2013. Southeast Asia Energy Outlook 2013. World Energy Outlook. Paris, France: IEA/OECD Organisation for Economic Co-operation and Development.

Kyuma, K., and Kawaguchi, K. 1966. Major Soils of Southeast Asia and the Classification of Soils under Rice Cultivation (Paddy Soils). Tonan Ajia Kenkyu 4(2): 290-312. https://kyoto-seas.org/ pdf/4/2/040207.pdf.

Mekong River Commission. 2009. Adaptation to climate change in the countries of the Lower Mekong Basin: Regional synthesis report. MRC Technical Paper. Number 24. ISSN:1683-1489.

Mekong River Commission. 2010. The first Mekong River Commission Summit 2010. 4-5 April 2010. Nam Ou, Luuk. 2015. Potential impacts of the Nam Ou 2 Dam on local livelihoods in Luang Prabang, Laos PDR. In Land and River Grabbing: The Mekong's Greatest Challenge, eds. C. Vaddhanaphuti and S. Gyorvary, 99-111. Chiang Mai University, Thailand: Center for ASEAN Studies.

Nijhuis, M., and D. Guttenfelder. 2015. Mekong River Dams. National Geographic Magazine. May 2015. http://ngm.nationalgeographic. com/2015/05/mekong-dams/nijhuis-text.

Olson, K.R., and L.W. Morton. 2017. Why were the soil tunnels of $\mathrm{Cu} \mathrm{Chi}$ and Iron Triangle in Vietnam so resilient? Open Journal of Soil Science 7:34-51. https://doi.org/10.4236/ ojss. 2017.72003 .

Vaddhanaphuti, C., and S. Gyorvary (eds). 2015. Land and River Grabbing: The Mekong's Greatest Challenge. Chiang Mai University, Thailand: Center for ASEAN Studies. The Regional Center for Social Sciences and Sustainable Development, Faculty of Social Sciences. 